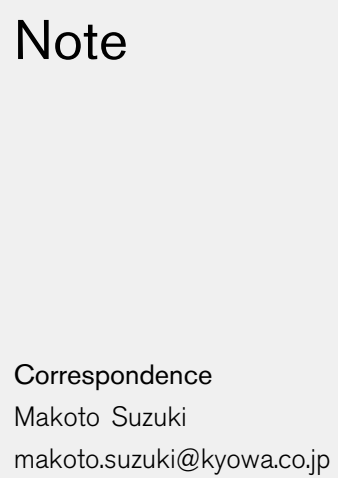

\section{Reichenbachia agariperforans gen. nov., sp. nov., a novel marine bacterium in the phylum Cytophaga- Flavobacterium-Bacteroides}

\author{
Olga I. Nedashkovskaya, ${ }^{1}$ Makoto Suzuki, ${ }^{2}$ Mikhail V. Vysotskii ${ }^{3}$ \\ and Valery $V^{\text {. Mikhailov }}{ }^{1}$
}

${ }^{1}$ Pacific Institute of Bioorganic Chemistry of the Far-Eastern Branch of the Russian Academy of Sciences, Pr. 100 Let Vladivostoku 159, 690022, Vladivostok, Russia
${ }^{2}$ Tokyo Research Laboratories, Kyowa Hakko Kogyo Co Ltd, 3-6-6 Asahi-machi, Machida-shi, Tokyo 194-8533, Japan

Institute of Marine Biology of the Far-Eastern Branch of the Russian Academy of Sciences, Pal'chevskogo St 17, 690032, Vladivostok, Russia

\begin{abstract}
A heterotrophic, pigmented, agarolytic, gliding bacterium was isolated from a seawater sample collected from the Gulf of Peter the Great, Sea of Japan, during June 2000. 16S rDNA sequence analysis indicated that the novel bacterium, strain $\mathrm{KMM} 3525^{\top}$, was a member of the phlyum Cytophaga-Flavobacterium-Bacteroides. On the basis of phenotypic, chemotaxonomic, genotypic and phylogenetic data, it is proposed that the marine bacterium represents the sole species of a novel genus, Reichenbachia, the type species of which is Reichenbachia agariperforans (KMM $3525^{\top}=$ IFO $16625^{\top}=$ JCM $11238^{\top}$ ).
\end{abstract}

Gliding, Gram-negative, heterotrophic bacteria are widely distributed in marine coastal ecosystems. Historically, bacteria belonging to the phylum Cytophaga-FlavobacteriumBacteroides (CFB) have been poorly investigated in terms of their phylogeny. During the last decade, many novel taxa belonging to the phylum CFB have been described, and some bacterial species that previously had unclear taxonomic positions within this phylum have been reclassified due to the use of a polyphasic taxonomic approach. Descriptions of genera such as Polaribacter, Gelidibacter, Psychroserpens, Psychroflexus and Salegentibacter have resulted from intensive studies into the microbial communities of Antarctic seas and hypersaline lakes (Gosink et al., 1998; Bowman et al., 1997, 1998; McCammon \& Bowman, 2000). Novel bacteria have also been found in shore marine waters in temperate latitudes, and the novel genera Cellulophaga, Tenacibaculum and Arenibacter have been created for these organisms (Johansen et al., 1999; Suzuki et al., 2001; Ivanova et al., 2001). However, many other taxa belonging to the phylum CFB remain to be described. In this study, we have characterized a novel bacterium, strain KMM $3525^{\mathrm{T}}$, which was isolated from a seawater sample. On the basis of the results of a polyphasic taxonomic study (i.e. phylogenetic, phenotypic and genotypic analyses, and analyses of menaquinone and cellular fatty acid compositions) on this novel

Abbreviation: CFB, Cytophaga-Flavobacterium-Bacteroides.

The GenBank accession number for the 16S rDNA sequence of Reichenbachia agariperforans KMM $3525^{\top}$ is AB058919. bacterium, we describe a novel genus of the phylum CFB, Reichenbachia, the type species of which is Reichenbachia agariperforans.

Agarolytic strain KMM $3525^{\mathrm{T}}$ was isolated from a seawater sample collected in the Amursky Bay of the Gulf of Peter the Great, Sea of Japan, during June 2000. The strain was cultured on Marine Agar 2216E (Difco). Flexirubin pigments of the strain were determined by the method of Fautz \& Reichenbach (1980). Determinations for the degradation of alginic acids $(1 \%, \mathrm{w} / \mathrm{v})$ and agar $(1 \cdot 5 \%, \mathrm{w} / \mathrm{v})$, growth at different temperatures, $\mathrm{NaCl}$ concentrations or $\mathrm{pH}$, production of acid from carbohydrates, and hydrolysis of starch, casein, gelatin, cellulose [carboxymethylcellulose (CM-cellulose) and filter paper], DNA and urea by strain KMM $3525^{\mathrm{T}}$ were carried out according to the methods of Smibert \& Krieg (1994). Hydrolysis of chitin ( $1 \%$, w/v) by strain KMM $3525^{\mathrm{T}}$ was determined by the appearance of clear zones around colonies on chitin agar. Susceptibility of the novel strain to antibacterials was examined by the routine disc-diffusion plate method. Discs were impregnated with the following antibacterials: ampicillin $(10 \mu \mathrm{g})$; benzylpenicillin $(10 \mu \mathrm{g})$; carbenicillin $(100 \mu \mathrm{g})$; gentamicin $(10 \mu \mathrm{g})$; kanamycin $(30 \mu \mathrm{g})$; lincomycin $(15 \mu \mathrm{g})$; neomycin $(30 \mu \mathrm{g})$; oleandomycin $(15 \mu \mathrm{g})$; polymyxin B (300 U); streptomycin $(10 \mu \mathrm{g})$; tetracycline $(30 \mu \mathrm{g})$.

The analysis of fatty acid methyl esters of the novel strain was performed by GLC $(30 \mathrm{~m} \times 0.25 \mathrm{~mm}$ Supelcowax 10 column, $205^{\circ} \mathrm{C}$ ) as described by Svetashev et al. (1995). 
Isoprenoid quinones were extracted and analysed by the method of Nakagawa \& Yamasato (1993). DNA was isolated from strain KMM $3525^{\mathrm{T}}$ following the method of Marmur (1961) and the G+C content (mol\%) of the DNA was determined by the thermal denaturation method (Marmur \& Doty, 1962). The 16S rRNA gene sequence of strain KMM $3525^{\mathrm{T}}$ was determined by PCR amplification and direct sequencing (Hiraishi, 1992). Conditions and reagents used for PCR amplification and sequencing of the $16 \mathrm{~S}$ rDNA have been described previously (Suzuki et al., 2001). The $16 \mathrm{~S}$ rDNA sequence of strain KMM $3525^{\mathrm{T}}$ was aligned with sequences retrieved from the databases by using CLUSTAL $\mathrm{W}$ (Thompson et al., 1994). The aligned sequences were modified manually according to the secondary structure of the Escherichia coli 16S rRNA gene sequence (Gutell et al., 1994). The regions in which the secondary structure of the rRNA of the analysed strains varied (positions 194-220, 450-487, 1284-1289, E. coli numbering system) and the sequences before position 111 and after position 1376, for which sequences of some reference organisms had not been determined, were excluded from the analysis. Evolutionary distances were then computed by using DNADIST contained within the PHYLIP package (version 3.572; Felsenstein, 1995) with the Kimura two-parameter correction (Kimura, 1980), and the phylogenetic tree was constructed by using the neighbour-joining method (Saitou \& Nei, 1987). To evaluate the stability of the phylogenetic tree, a bootstrap analysis (1000 replications) was performed with the SEQBOOT and CONSENSE programs contained within the PHYLIP package (version 3.572).

Strain KMM $3525^{\mathrm{T}}$ was a Gram-negative, chemoorganotrophic bacterium with a respiratory-type metabolism. It was motile by gliding and appeared as single, flexible rods of $0 \cdot 5-0 \cdot 7 \mu \mathrm{m}$ in diameter and 5-15 $\mu \mathrm{m}$ in length. On marine agar, colonies were round, $3-5 \mathrm{~mm}$ in diameter, orange-pigmented and formed deep hollows in agar plates. The organism had no known resting stages. Strain KMM $3525^{\mathrm{T}}$ was oxidase-, catalase- and alkaline-phosphatasepositive, and required $\mathrm{Na}^{+}$ions for growth. Growth of the organism occurred in media containing $1-6 \% \mathrm{NaCl}$. The temperature range for growth was $4-35^{\circ} \mathrm{C}$, with optimum growth occurring at $28^{\circ} \mathrm{C}$. The $\mathrm{pH}$ range for growth was $5 \cdot 5-10 \cdot 0$, with optimum growth occurring between $\mathrm{pH} 7 \cdot 5$ and $8 \cdot 5$. Flexirubin pigments were formed by the novel bacterium. Agar, starch, alginate, gelatin, Tween 20, DNA and urea were degraded by strain KMM $3525^{\mathrm{T}}$, but cellulose (CM-cellulose and filter paper), chitin, casein, Tween 40, Tween 60 and Tween 80 were not hydrolysed by the strain. $\mathrm{H}_{2} \mathrm{~S}$ and indole were not produced by the bacterium and it formed no acid from arabinose, galactose, glucose, lactose, maltose, melibiose, rhamnose, sucrose, xylose, adonitol, dulcitol, inositol or mannitol. Utilization of citrate, fumarate and malate as sole carbon sources was not observed. Nitrate reduction was negative. Strain KMM $3525^{\mathrm{T}}$ was susceptible to carbenicillin, oleandomycin, lincomycin and tetracycline, but it was not susceptible to ampicillin, benzylpenicillin, streptomycin, gentamicin, neomycin or polymyxin B. Predominant cellular fatty acids were straightchain unsaturated and branched-chain saturated, namely $\mathrm{C}_{\mathrm{i} 15: 0}(55 \cdot 6 \%)$ and $\mathrm{C}_{16: 1(\mathrm{n}-7)}(23 \cdot 7 \%)$ fatty acids. The DNA $\mathrm{G}+\mathrm{C}$ content of the novel strain was $44.5 \mathrm{~mol} \%$, as determined by the thermal denaturation method.

A phylogenetic analysis of the $16 \mathrm{~S}$ rDNA sequence data revealed that strain KMM $3525^{\mathrm{T}}$ formed a distinct lineage within the phylum CFB and belonged to a cluster containing Persicobacter diffluens and marine flexibacteria (Fig. 1), but this was without significant bootstrap support. The members of this cluster share many phenotypic traits. Features useful for distinguishing strain $\mathrm{KMM} 3525^{\mathrm{T}}$ from related members of the phylum CFB are listed in Table 1. The marine flexibacteria were separated from the genus Flexibacter and placed into the genus Microsilla by Pringsheim (1951); the taxonomy of this polyphyletic group was studied by Lewin (1969). More recently, on the basis of $16 \mathrm{~S}$ rRNA gene sequence data, Nakagawa et al. (1997) have suggested that the genus Microscilla be restricted to a single species, Microscilla marina, the type species and only member of this taxon, which occupies a separate phylogenetic lineage within the phylum $\mathrm{CFB}$. The taxonomic positions of other species of marine flexibacteria belonging to different rDNA branches are unclear and need further investigation (Bernardet et al., 1996; Nakagawa et al., 1997; Sly et al., 1998). The $16 \mathrm{~S}$ rDNA sequence of strain KMM $3525^{\mathrm{T}}$ was most similar to that of 'Microscilla sericea' ( $89 \cdot 5 \%)$. Its level of $16 \mathrm{~S} \mathrm{rDNA}$ sequence similarity with other members of the phylum CFB ranged from $79 \cdot 1$ to $89 \cdot 1 \%$. Such low levels of sequence similarity of strain $\mathrm{KMM} 3525^{\mathrm{T}}$ with other marine flexibacteria clearly demonstrate that the novel bacterium described in this study represents a novel genus within the phylum CFB. This conclusion, supported by the polyphasic data presented in this study, demonstrates that strain $\mathrm{KMM} 3525^{\mathrm{T}}$ could not be assigned to any of the currently recognized genera included in the phylum CFB. Thus, we propose that strain KMM $3525^{\mathrm{T}}$ be placed into a novel genus, Reichenbachia, as Reichenbachia agariperforans.

\section{Description of Reichenbachia gen. nov.}

Reichenbachia (Rei.chen.bach'i.a. N.L. fem. n. Reichenbachia after Hans Reichenbach, a German microbiologist, who has made a great contribution to the taxonomy of bacteria belonging to the phylum CFB).

Rod-shaped cells with gliding motility. Gram-negative. Does not form endospores or resting stages. Requires $\mathrm{Na}^{+}$ions for growth. Strictly aerobic. Produces non-diffusible orange pigment. Flexirubins are synthesized. Chemo-organotroph. Cytochrome-oxidase-, catalase- and alkaline-phosphatasepositive. Major respiratory quinone is MK-7. The main cellular fatty acids are straight-chain unsaturated and branched-chain saturated fatty acids, $\mathrm{C}_{115: 0}$ and $\mathrm{C}_{16: 1(\mathrm{n}-7)}$. As determined by $16 \mathrm{~S}$ rDNA sequence analysis, the genus Reichenbachia is a member of the phylum CFB. The type species is Reichenbachia agariperforans. 


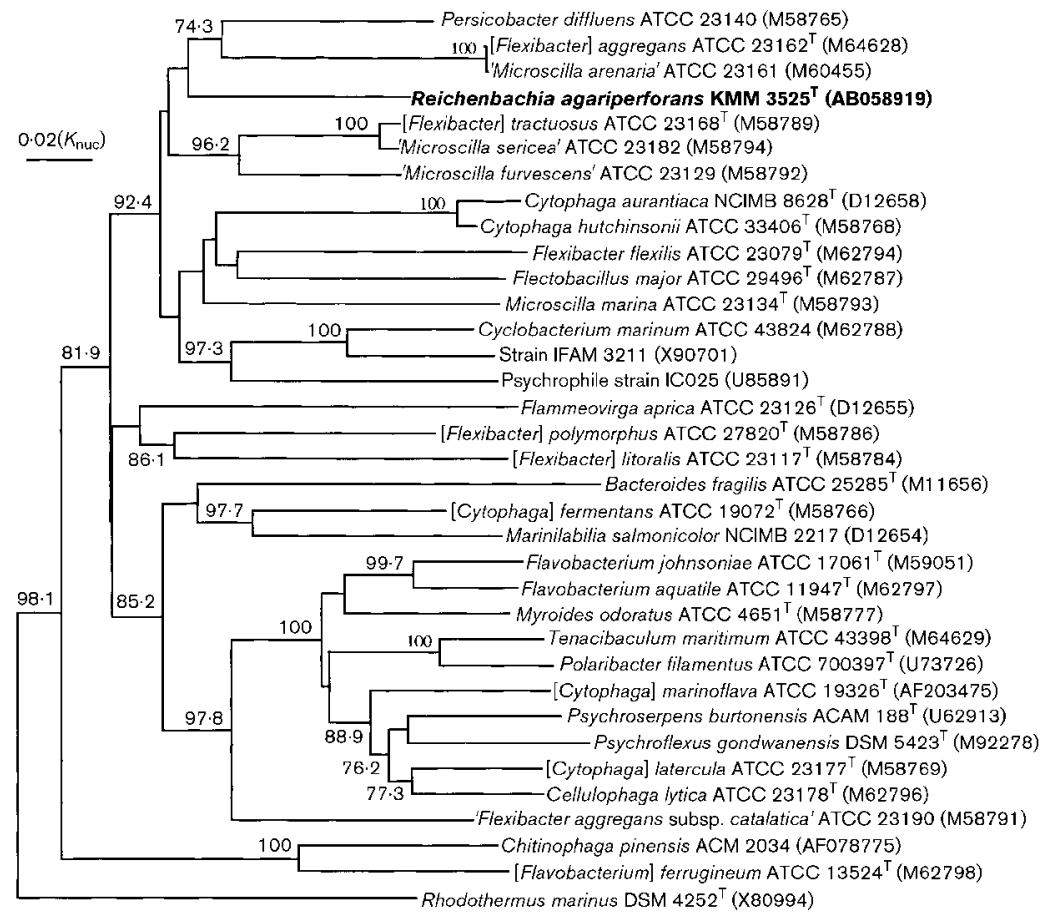

Fig. 1. Phylogenetic relationship of Reichenbachia agariperforans KMM $3525^{\top}$ with other species of the phylum CFB on the basis of 16S rDNA sequence comparisons. The phylogenetic tree was generated by the neighbour-joining method (Saitou \& Nei, 1987 ), and the 16S rDNA sequence of Rhodothermus marinus was used as the outgroup. The numbers shown at the nodes indicate the percentage bootstrap values (based on 1000 replications; only values of $\geqslant 70 \%$ are shown). Bar, genetic distance of $0.02\left(K_{\text {nuc }}\right)$.

\section{Description of Reichenbachia agariperforans sp. nov.}

Reichenbachia agariperforans [a.ga.ri.per.fo' rans. Malayan n. agar agar; N.L. n. agarum agar (algal polysaccharide); L. part. adj. perforans perforating (making holes); N.L. part. adj. agariperforans making holes in agar, bacterium making deep hollows in agar].

Main characteristics are those given for the genus. In addition to the above data, cells are $0 \cdot 5-0 \cdot 7 \mu \mathrm{m}$ in width and $5-15 \mu \mathrm{m}$ in length. Colonies are $3-5 \mathrm{~mm}$ in diameter,

Table 1. Characteristics useful in distinguishing strain $\mathrm{KMM} 3525^{\top}$ from related marine genera of the phylum $\mathrm{CFB}$

Species/taxon: 1, strain KMM 3525 ${ }^{\mathrm{T}}$; 2, Cytophaga hutchinsonii; 3, 'Microscilla furvescens'; 4, 'Microscilla sericea'; 5, [Flexibacter] tractuosus; 6, Marinilabillia salmonicolor; 7, [Cytophaga] fermentans; 8, Persicobacter diffluens; 9, Flammeovirga aprica; 10, Microscilla marina; 11, Cyclobacterium marinum; 12, [Flexibacter] aggregans; 13, [Flexibacter] polymorphus; 14, [Flexibacter] litoralis. Data are from Reichenbach (1989), Lewin \& Lounsbery (1969), Nakagawa et al. (1997), Suzuki et. al. (1999), Raj \& Maloy (1990) and this study. ND, Not determined; + , positive; -, negative; $\mathrm{V}$, variable; A, strict aerobe; F, facultative anaerobe.

\begin{tabular}{|c|c|c|c|c|c|c|c|c|c|c|c|c|c|c|}
\hline Test & 1 & 2 & 3 & 4 & 5 & 6 & 7 & 8 & 9 & 10 & 11 & 12 & 13 & 14 \\
\hline Oxidase/catalase & $+1+$ & $+1-$ & ND & ND & ND & $+1+$ & $-1-$ & $+1-$ & $+1-$ & $+1+$ & $+1+$ & $+/+$ & $\mathrm{ND} /-$ & $\mathrm{ND} /-$ \\
\hline Gliding motility & + & + & + & + & + & + & + & + & + & + & - & + & + & + \\
\hline $\begin{array}{l}\text { Requirement for } \mathrm{Na}^{+} \text {or } \\
\text { seawater for growth }\end{array}$ & + & - & $\mathrm{ND}$ & + & - & + & + & + & + & + & + & + & + & + \\
\hline Agar & + & - & + & - & - & $\mathrm{V}$ & + & + & + & - & - & + & - & - \\
\hline Gelatin & + & ND & + & + & $\mathrm{V}$ & + & ND & + & + & + & - & - & + & + \\
\hline Casein & - & ND & $\mathrm{ND}$ & ND & $\mathrm{ND}$ & + & $\mathrm{ND}$ & - & - & $\mathrm{ND}$ & - & - & $\mathrm{ND}$ & $\mathrm{ND}$ \\
\hline Starch & + & - & + & + & $\mathrm{V}$ & + & + & + & + & - & - & - & - & + \\
\hline
\end{tabular}


circular, sunken into agar and shiny with entire edges on solid media containing high-nutrient components. Growth occurs at $4-35^{\circ} \mathrm{C}$; optimal temperature range for growth is $25-28^{\circ} \mathrm{C}$. Growth occurs in presence of $1-6 \% \mathrm{NaCl}$. Decomposes agar, starch, alginate, gelatin, DNA, urea and Tween 20. Does not hydrolyse cellulose (CM-cellulose and filter paper), chitin, casein, Tween 40, Tween 60 or Tween 80. Forms no acid from arabinose, galactose, glucose, lactose, maltose, melibiose, rhamnose, sucrose, xylose, adonitol, dulcitol, inositol or mannitol. Does not utilize citrate, fumarate or malate. Nitrate is not reduced. Does not produce $\mathrm{H}_{2} \mathrm{~S}$ or indole. DNA G $+\mathrm{C}$ content is $44.5 \mathrm{~mol} \%$. Type strain is KMM $3525^{\mathrm{T}}\left(=\mathrm{IFO} 16625^{\mathrm{T}}=\mathrm{JCM} 11238^{\mathrm{T}}\right)$. Isolated from a seawater sample collected in the Amursky Bay of the Gulf of Peter the Great, Sea of Japan.

\section{Acknowledgements}

We gratefully thank Dr Chantal Bizet (Collection de Bacteries de l'Institute Pasteur, Paris, France) and Dr Danielle Janssens (Culture Collection of the Laboratory of Microbiology, University of Gent, Belgium) for the type strains used in this study. This research was supported by grants from the Foundation of the Ministry for Industry and Science of the Russian Federation (MIS RF) (95-01/03-19), the Biodiversity Programme of the Russian Academy of Science and MIS RF, and the Russian Foundation for Basic Research (02-04-49517).

\section{References}

Bernardet, J.-F., Segers, P., Vancanneyt, M., Berthe, F., Kersters, K. \& Vandamme, P. (1996). Cutting a Gordian knot: emended classification and description of the genus Flavobacterium, emended description of the family Flavobacteriaceae, and proposal of Flavobacterium hydatis nom. nov. (basonym, Cytophaga aquatilis Strohl and Tait 1978). Int J Syst Bacteriol 46, 128-148.

Bowman, J. P., McCammon, S. A., Brown, J. L., Nichols, P. D. \& McMeekin, T. A. (1997). Psychroserpens burtonensis gen. nov., sp. nov., and Gelidibacter algens gen. nov., sp. nov., psychrophilic bacteria isolated from Antarctic lacustrine and sea ice habitats. Int J Syst Bacteriol 47, 670-677.

Bowman, J. P., McCammon, S. A., Lewis, T., Skerratt, J. H., Brown, J. L., Nichols, D. S. \& McMeekin, T. A. (1998). Psychroflexus torquis gen. nov., sp. nov., a psychrophilic species from Antarctic sea ice, and reclassification of Flavobacterium gondwanense (Dobson et al. 1993) as Psychroflexus gondwanense gen. nov., comb. nov. Microbiology 144, 1601-1609.

Fautz, E. \& Reichenbach, H. (1980). A simple test for flexirubin-type pigments. FEMS Microbiol Lett 8, 87-91.

Felsenstein, J. (1995). PHYLIP (phylogeny inference package), version 3.57c. Department of Genetics, University of Washington, Seattle, USA.

Gosink, J. J., Woese, C. R. \& Staley, J. T. (1998). Polaribacter gen. nov., with three new species, $P$. irgensii sp. nov., $P$. franzmannii sp. nov. and $P$. filamentus sp. nov., gas vacuolate polar marine bacteria of the Cytophaga-Flavobacterium-Bacteroides group and reclassification of 'Flectobacillus glomeratus' as Polaribacter glomeratus comb. nov. Int J Syst Bacteriol 48, 223-235.
Gutell, R. R., Larsen, N. \& Woese, C. R. (1994). Lessons from an evolving rRNA: $16 \mathrm{~S}$ and $23 \mathrm{~S}$ rRNA structures from a comparative perspective. Microbiol Rev 58, 10-26.

Hiraishi, A. (1992). Direct automated sequencing of $16 \mathrm{~S}$ rDNA amplified by polymerase chain reaction from bacterial cultures without DNA purification. Lett Appl Microbiol 15, 210-213.

Ivanova, E. P., Nedashkovskaya, O. I., Chun, J. \& 7 other authors (2001). Arenibacter gen. nov., new genus of the family Flavobacteriaceae and description of a new species, Arenibacter latericius sp. nov. Int J Syst Evol Microbiol 51, 1987-1995.

Johansen, J. E., Nielsen, P. \& Sjøholm, C. (1999). Description of Cellulophaga baltica gen. nov., sp. nov. and Cellulophaga fucicola gen. nov., sp. nov. and reclassification of [Cytophaga] lytica to Cellulophaga lytica gen. nov., comb. nov. Int J Syst Bacteriol 49, 1231-1240.

Kimura, M. (1980). A simple method for estimating evolutionary rates of base substitutions through comparative studies of nucleotide sequences. J Mol Evol 16, 111-120.

Lewin, R. A. (1969). A classification of flexibacteria. J Gen Microbiol 58, 189-206.

Lewin, R. A. \& Lounsbery, D. M. (1969). Isolation, cultivation, and characterization of flexibacteria. J Gen Microbiol 58, 145-170.

Marmur, J. (1961). A procedure for the isolation of deoxyribonucleic acid from microorganisms. J Mol Biol 3, 208-218.

Marmur, J. \& Doty, P. (1962). Determination of the base composition of deoxyribonucleic acid from its thermal denaturation temperature. J Mol Biol 5, 109-118.

McCammon, S. A. \& Bowman, J. P. (2000). Taxonomy of Antarctic Flavobacterium species: description of Flavobacterium gillisiae sp. nov., Flavobacterium tegetincola sp. nov. and Flavobacterium xanthum sp. nov., nom. rev., and reclassification of [Flavobacterium] salegens as Salegentibacter salegens gen. nov., comb. nov. Int J Syst Evol Microbiol 50, 1055-1063.

Nakagawa, Y. \& Yamasato, K. (1993). Phylogenetic diversity of the genus Cytophaga revealed by $16 \mathrm{~S}$ rRNA sequencing and menaquinone analysis. J Gen Microbiol 139, 1155-1161.

Nakagawa, Y., Hamana, K., Sakane, T. \& Yamasato, K. (1997). Reclassification of Cytophaga aprica (Lewin 1969) Reichenbach 1989 in Flammeovirga gen. nov. as Flammeovirga aprica comb. nov. and of Cytophaga diffluens (ex Stanier 1940; emend. Lewin 1969) Reichenbach 1989 in Persicobacter diffluens comb. nov. Int J Syst Bacteriol 47, 220-223.

Pringsheim, E. G. (1951). The Vitreoscillaceae: a family of colourless, gliding, filamentous organisms. J Gen Microbiol 5, 124-149.

Raj, H. D. \& Maloy, S. R. (1990). Proposal of Cyclobacterium marinus gen. nov., comb. nov. for a marine bacterium previously assigned to the genus Flectobacillus. Int J Syst Bacteriol 40, 337-347.

Reichenbach, H. (1989). Order I. Cytophagales Leadbetter 1974, 99 ${ }^{\mathrm{AL}}$. In Bergey's Manual of Systematic Bacteriology, vol. 3, pp. 2011-2073. Edited by J. T. Staley, M. P. Bryant, N. Pfennig \& J. G. Holt. Baltimore: Williams \& Wilkins.

Saitou, N. \& Nei, M. (1987). The neighbor-joining method: a new method for reconstructing phylogenetic trees. Mol Biol Evol 4, 406425 .

Sly, L. I., Taghavi, M. \& Fegan, M. (1998). Phylogenetic heterogeneity within the genus Herpetosiphon: transfer of the marine species Herpetosiphon cohaerens, Herpetosiphon nigricans and Herpetosiphon persicus to the genus Lewinella gen. nov. in the FlexibacterBacteroides-Cytophaga phylum. Int J Syst Bacteriol 48, 731-737.

Smibert, R. M. \& Krieg, N. R. (1994). Phenotypic characterization. In Methods for General and Molecular Bacteriology, pp. 607-654. Edited 
by P. Gerhardt, R. G. E. Murray, W. A. Wood \& N. R. Krieg. Washington, DC: American Society for Microbiology.

Suzuki, M., Nakagawa, Y., Harayama, S. \& Yamamoto, S. (1999). Phylogenetic analysis of genus Marinilabilia and related bacteria based on the amino acid sequences of GyrB and emended description of Marinilabilia salmonicolor with Marinilabilia agarovorans as its subjective synonym. Int J Syst Bacteriol 49, 1551-1557.

Suzuki, M., Nakagawa, Y., Harayama, S. \& Yamamoto, S. (2001).

Phylogenetic analysis and taxonomic study of marine Cytophaga-like bacteria: proposal for Tenacibaculum gen. nov. with Tenacibaculum maritimum comb. nov. and Tenacibaculum ovolyticum comb. nov., and description of Tenacibaculum mesophilum sp. nov. and Tenacibaculum amylolyticum sp. nov. Int J Syst Evol Microbiol 51, 1639-1652.

Svetashev, V. I., Vysotskii, M. V., Ivanova, E. P. \& Mikhailov, V. V. (1995). Cellular fatty acids of Alteromonas species. Syst Appl Microbiol 18, 37-43.

Thompson, J. D., Higgins, D. G. \& Gibson, T. J. (1994). CLUSTAL W: improving the sensitivity of progressive multiple sequence alignment through sequence weighting, position-specific gap penalties and weight matrix choice. Nucleic Acids Res 22, 4673-4680. 